\title{
Breast Carcinoma Metastatic in the Bone
}

National Cancer Institute

\section{Source}

National Cancer Institute. Breast Carcinoma Metastatic in the Bone. NCI Thesaurus.

Code C36303.

A carcinoma that arises from the breast and has metastasized to the bone. 